\title{
Trade Unions and Work-life Balance: Changing Times in France and the UK?
}

\author{
Abigail Gregory and Susan Milner
}

\begin{abstract}
The mixed empirical findings to date have indicated that some, but not all, unions in industrialized countries are actively involved in campaigning and bargaining around work-life balance (WLB) issues, as part of a modernization agenda linked to feminization and to 'positive flexibility'. This article seeks to identify factors that might encourage or inhibit trade unions from involvement in WLB issues, within a cross-national comparative perspective focusing on two countries (France and the UK) that have contrasting working time regimes and approaches to WLB. It draws on original research carried out in two sectorsinsurance and social work - in these two countries. The article links the emergence of union WLB programmes and bargaining agendas to genderequality concerns within the union and to the gender composition of the sector, as well as to the working time regime, including the mode of action, partnership being a significant corollary of WLB campaigning in the UK. We find support for the modernization thesis in the UK, particularly in the public sector, but within severe constraints defined by employer initiative.
\end{abstract}

\section{Introduction}

Work-life balance ${ }^{1}$ (WLB) has become the focus of growing public and policy interest, both internationally and within the EU, in the context of socio-demographic changes, in particular, increased female labour market participation, and of business objectives concerning employees' performance and productivity.

Within the EU the policy interest in 'reconciliation of work and family' has directly generated measures at both EU and nation-state level, such as the EU directives on parental leave and part-time work and the EU Council of Ministers' resolution of 29 June 2000, calling for the development of paternity leave. In EU social policy, exhortation has also come for social partners to negotiate the modernization of working time to generate "positive 
flexibility', that is, to say the 'synchronization of employer and employee time needs . . . contributing to sustainable work-life balance policies for employees as well as a high performance workplace' (Morris and Pillinger 2007: 208). In addition, the EU's focus on promoting gender equality (notably through its Framework Strategy for Gender Equality and through the introduction of 'gender mainstreaming' in policy design and evaluation) has also strongly implicated the social partners in its realization and has, to varying degrees, fed into national legislation and collective agreements in the area of WLB (Demetriades et al. 2006; Kirton and Greene 2005). Trade union involvement in the implementation of WLB policies corresponds to a shift from hard law to soft law and to concerns around implementation of such policies (Hantrais 2000).

In the USA, the UK and many other countries where there is public policy interest in WLB, trade unions have been considered to have an important role to play in improving workplace provision for employees. For instance, the UK's Women and Work Commission, reporting in February 2006, recommended that 'Trade unions should train their representatives to promote the benefits of flexible working options and win hearts and minds among management and employees for best practice policies and procedures to monitor the right to request flexible working' (Women and Work Commission 2006: 7).

Conflicting views have been voiced about the role of trade unions in relation to developing the WLB agenda. Some have seen them as being only weakly committed to WLB policies and barely present in the process of introducing them in the workplace (Hantrais and Ackers 2005). Two broad reasons are advanced to explain unions' apparent lack of investment in WLB policies: first, such policies are seen as 'women's' issues and as such clash with masculine cultures of male-dominated unions (Dickens et al. 1988); second, WLB measures typically encompass flexible working, which poses challenges as it is often seen by unions as a removal of collective, protective rights, and is usually employer led rather than employee or trade union led (Ackers 2002; Colling and Dickens 2001; Kirton and Greene 2006). Fleetwood (2007) suggests that the WLB agenda has been driven by business concerns that effectively disguise employer-friendly measures in an employee-friendly discourse.

The definition of 'flexible working' is, of itself, highly ambiguous, as it can comprise a range of organizational strategies including, for example, functional, contractual, numerical, financial and geographical flexibility, each differing in the extent to which the flexibility solely benefits employers or is of mutual benefit to employees and employers (Lewis and Cooper 2005: 3). Flexibility in working time can be 'employee-friendly' flexibility, such as term-time working, job-sharing, flexi-time and parental leave and enhance WLB, but it can also be 'employer-friendly' and comprise practices such as zero-hour contracts, on-call systems and shift working, which tend to render it harder to balance paid work and other commitments. A number of forms of flexible working (e.g. annualized working, homeworking and part-time

(C) Blackwell Publishing Ltd/London School of Economics 2009. 


\section{4}

working) can be perceived variously as employee-friendly or employerfriendly, depending on the context, as we discuss below.

Furthermore, in some national contexts where the state intervenes in family policy and/or employment policy, unions may lack commitment to workplace policies on WLB, because they see them as falling under the remit of the state. This applies for example in the case of France (Lanquetin et al. 2000).

For other commentators, trade unions do not lack commitment to WLB policies, but rather lack power and influence in the workplace: 'Unions overall ... do not appear to have great power to hold back the insidious processes of the intensification of work' (Gambles et al. 2006: 51; see also Hyman and Summers 2007). Unions have modernized their policies and their internal organization and practice, but paradoxically they have done so at a time when their capacity to intervene is greatly reduced (Colling and Dickens 2001).

Correspondingly, empirical evidence of the impact of trade unions in developing WLB measures is mixed (Bardoel et al. 1999; Bewley and Fernie 2003; Budd and Mumford 2004; Gerstel and Clawson 2001; Wood et al. 2003). A European review of collective bargaining on WLB suggested that, between employer-friendly flexibility and legislator-led parental leaves, the space for trade union action is constricted (Demetriades et al. 2006).

Analysis of the relatively limited research in this area suggests that the opportunity structures for the negotiation of WLB measures by trade unions are located in three key areas. The first of these is gender politics. This has been seen where WLB is framed in terms of gender equality (Hardy and Adnett 2002), and has been formally promoted by the EU and by some national governments. For example, the EQUAL projects aimed at boosting employability, in accordance with the Lisbon employment targets of March 2000, saw a relatively high degree of trade union participation and resulted in practical WLB measures (EU 2007). Also, within the European Trade Union Confederation ETUC), the women's committee has campaigned actively for WLB.

Likewise, opportunity structures are predicted to open up where trade unions are feminized in terms of membership and particularly leadership (Ardura and Silvera 2001; Coleman and Hasting 1993; Gerstel and Clawson 2002; Trebilcock 1991). With trade unions in the EU developing convergent approaches and strategies to gender equality, not least in response to the EU's policy of gender mainstreaming (Kirton and Greene 2005: 146), we might then expect to see both a consequent rise in the proportion of women members and leaders and, accompanying this, a shift towards WLB issues in campaigns and bargaining, across European countries.

A second opportunity structure is that of the national working time regime. We define this as comprising the mode of regulation (the relationship between legislation and collective bargaining), which has been shown to be clearly related to the degree of trade-union involvement in bargaining on WLB in EU countries (Demetriades et al. 2006), and national working time 
priorities and patterns, which contribute towards determining the nature of trade union involvement. In line with the analyses cited above, we would expect unions' policies and initiatives to be strongly influenced by the opportunities and constraints presented by specific forms of employment flexibility and working-time arrangements.

A third opportunity structure is provided by the specific organization (and the sector in which it is located), as organizations have been shown to be key actors in the complex multi-level dynamics that result in WLB policy and practice (Gambles et al. 2006). Linked to this, the unions' relationship with management is likely to be a key factor (Colling and Dickens 2001).

In this article, we seek to identify factors that might encourage or inhibit trade unions from involvement in WLB issues, within a cross-national comparative perspective focusing on two countries (France and the UK) that have contrasting working time regimes. We draw on fieldwork carried out in France and in the UK between 2001 and 2005 in insurance and social work (see Gregory and Milner 2006). Before describing our findings, we briefly set out the working time regimes in France and in the UK, and the methodology for our fieldwork.

\section{The comparative context: working time regimes and WLB in France and in the UK}

Working time regimes in France and in the UK differ significantly because of contrasting configurations of the state, families and social partners in those countries (see Gregory and Milner 2008: 73; Rubery et al. 1998).

France has been characterized as a dirigiste regime, whereby legislation has traditionally played an important role in establishing work-time norms along with institutionalized bargaining; as a result, bargaining coverage is remarkably high (92 per cent + ) despite extremely low trade union membership. The relationship between legislation and collective bargaining has, however, undergone significant change in recent years, largely as a result of 'reform at the margins', which has taken the form of collectively agreed exemptions from legislative coverage, particularly on working time and on other forms of flexibility.

Work-time regulation in France has focused particularly on the reduction of working time, in line with union demands. Work-time legislation began in 1919 with the introduction of the eight-hour day and 48-hour week, and has progressively reduced working time (via reductions in the working week and increases in holiday entitlement) leading up to the most recent introduction of the 35-hour week via the Aubry Laws of 1998 and 2000. The rationale for this process has, however, varied. While earlier reductions were motivated by quality of life concerns, including a preoccupation with 'temps choisi' in the early 1980s (freedom of choice), the most recent reductions (1982 and 1998/ 2000) focused particularly on employment generation and productivity benefits of work-time reduction, where work-time reduction with no loss of pay 
is exchanged for work-time reorganization and flexibility (Fagnani and Letablier 2007). French work-time regulation limited work-time flexibility up to the early 1980 s, via regulations relating to the use of part-time work, shift work and overtime working, and which were progressively relaxed in the face of the international competitive pressure of the early 1980s.

In this context the discourse relating to WLB in France, spurred on by EU legislation and concerns, has been enacted primarily via family policy (e.g. the extension of existing parental leave provisions and of paternity leave) and equality policy, and to a lesser extent, through employment policy (Lanquetin et al. 2000). Although as a result of gender equality measures (the Roudy law of 1983 and the Génisson law of 2001) employers and trade unions were called upon by government to address WLB through collective bargaining, governments did not follow up this requirement in practice, probably because of a lack of political will (Jobert 1994; Lanquetin et al. 2000; Laufer 1998). Moreover, trade unions have not tended to see this as a workplace issue, reflecting employees' view that WLB is a state responsibility rather than a workplace issue. The lack of proactivity in this area may also reflect the French union movement's general reluctance to adopt a neoliberal line. Of the major French unions, only the Confédération Française Démocratique du Travail (CFDT) has relaxed a hard-line, non-conciliatory approach towards bargaining over flexibility following the reduction of working time to 39 hours in 1982. The unions' traditional role has therefore been one of lobbying government on family policy (notably through the annual family policy conference) and on gender equality through ministerial departments on women and equality.

Bargaining over WLB nevertheless resulted from the Aubry laws of 1998/ 2000 on working-time reduction, which had led to an unprecedented but temporary rise in bargaining, and from the 2001 Génisson law, making bargaining on equality compulsory at company level (annually) and sectoral level (every three years). Bargaining specifically on the Génisson law was backed up by a 2004 inter-sectoral agreement on gender equality and gender balance in the workforce. Collective agreements issuing from this law relate particularly to maternity leave and benefits and to a lesser extent to paternity leave (Demetriades et al. 2006).

The Aubry laws appear to have had mixed results for employees, with a majority of employees of both sexes reporting improved WLB, but with a sizeable minority complaining of work intensification and greater work stress (Fagnani and Letablier 2007). The bargaining process within the organization has been a major factor influencing outcomes for employees, with public sector employees doing rather better than their private-sector counterparts. Bargaining on the 35-hour week helped to promote a trade union agenda of 'positive flexibility', particularly for the CFDT, which already advocated this agenda; however many unions continued to view employer-friendly flexibility, particularly annualized hours, with distrust. With employers much stronger at workplace level than unions, decentralized bargaining in the private sector proved to be a 'Trojan horse' for forms of flexibility which unions had hitherto combated (Jefferys 2000). 
In contrast with France, the UK is traditionally characterized as having a laisser-faire system of regulation, with limited state intervention and high salience of collective bargaining. As a result, work-time regulation is patchy and the UK is seen as a country typified by long male weekly working hours and a relatively high use of overtime on one hand, and a high incidence of female part-time work (linked to a persistent gender pay gap) on the other (Franco and Winqvist 2002; Walby and Olsen 2002). In contrast with France, where levels of part-time working are still relatively low, despite growth since the 1980s (Le Feuvre and Lemarchant 2007), in Britain, part-time working is more widespread and is used as an adaptive strategy by mothers. It is strongly associated with 'atypical' working and also, disproportionately, with antisocial working, where overtime is unpaid or underpaid and the employee has little control over hours (see Rubery et al. 1998).

In a voluntaristic employment culture, legal rights can often remain merely formal without unions or other actors to enforce implementation; hence unions are seen as having a key role to play in the UK (Bagilhole and Byrne 2000; Colling and Dickens 2001). Trade union involvement in the introduction and/or implementation of WLB measures in the workplace suggests a shift in their role, from traditional forms of wage and wage-related bargaining, towards information provision and facilitation, or assisting individuals in accessing and taking up policies (Budd and Mumford 2004). It also demonstrates programmatic modernization around the idea of "positive flexibility', as Morris and Pillinger (2007) have demonstrated in relation to WLB development in the public sector, and an accompanying modernization of modes of action, with a shift from distributive to integrative bargaining (Cressey 2002; Heery 2006a,b). An emphasis on gender equality and antidiscrimination measures, accompanied by internal (organizational) change, underpins this shift (Colling and Dickens 2001; Heery 2006a,b). However, trade unions have struggled to make their voice heard (Demetriades et al. 2006: 57-64).

Although the Trade Union Congress (TUC) has consistently joined other European unions in calling for reduced working time, the UK government has traditionally resisted legislation in this area, and obtained an exemption from the EU Working Time Directive, allowing individuals to opt out of the 48-hour weekly limit on working time. Even then the directive was only implemented in the UK in the late 1990s, several years after its adoption. Likewise in relation to work-time flexibility, the UK's liberal regime has placed few constraints. Legislation requiring equal treatment between parttime and full-time workers was introduced, again under EU pressure, in 2000. New rights for working parents were set out in the 1999 Employment Relations Act, the 2002 Employment Act and the 2006 Work and Families Act. The rationale for these legislative measures is partly to compensate for the loss of trade union protection and bargaining coverage (down to 35 per cent of employees, and as low as 26 per cent in the private sector: Kersley et al. 2006), and partly to promote a parent-friendly discourse in which WLB is presented as a 'win-win' strategy for business and employees. A key feature of

(C) Blackwell Publishing Ltd/London School of Economics 2009. 
the 2002 Employment Act is the possibility for parents of children under six years old to request flexibility in their working hours for childcare reasons. Again, however, the TUC argues that this right is strongly impeded in practice by employer objections on business grounds.

In sum, the WLB discourse and agenda has grown in importance in both France and in the UK, but has been addressed differently in the two countries. While legislation has played an important role (reduction in working time and equality legislation in France and family-friendly legislation in the UK), the role of the trade unions has differed, with British unions seemingly more fully implicated in a neoliberal approach, accepting that business concerns for flexibility and increased service requirements are paramount.

\section{Evidence from sector case studies}

Our article stems from a wider project on family-friendly and WLB policies in insurance and social work in France and the UK, funded by the French Family Benefit Agency (Caisse Nationale des Allocations Familiales) and with additional funding from the British Academy (see Gregory and Milner 2006). This project, carried out between 2001 and 2005, was based on a questionnaire, which we distributed to human resources (HR) officers in the major insurance companies and local authorities in both countries. The questionnaire focused on the availability and take-up of WLB measures and the reasons for and mode of adoption of such measures. Following the questionnaire, we carried out semi-structured interviews with corporate HR officers, line managers, trade union representatives and a small number of employed parents in two case-study organizations in each sector in each country.

During the project we interviewed trade union representatives at national level (the national confederations TUC in the UK, Confédération Générale $\mathrm{du}$ Travail (CGT) and CFDT in France; federations belonging to these national confederations in France and the TUC affiliated unions Unison and UNIFI in the UK) and in our case-study organizations in insurance and social work. ${ }^{2}$ The sector and the workplace determine the unions to which we had access for the study. Both sectors had relatively high levels of unionization, particularly high for social work and above the national average in both countries for insurance. All but one of our case-study organizations had trade union representatives.

The questionnaire returns from HR managers or other relevant respondents $^{3}$ indicated that union influence in the formulation of WLB policies and measures was very limited (to between 7 per cent and 10 per cent of responding organizations), except in social work in the UK, where around 38 per cent of organizations reported that trade unions had taken the initiative. In line with other studies (e.g. Hyman and Summers 2007), HR officers were more likely to report benchmarking and staff recruitment and retention as key drivers in the adoption of WLB measures, particularly in the UK. Nevertheless, in the French case, it should be noted that union representatives can be 
present on works committees (comités d'entreprise, obligatory in companies or workplaces with 50 employees and over) and that these forums not only have an obligation to discuss working time in the organization on an annual basis, but are also often responsible for enhancing WLB policies. Hence, in our questionnaire survey we found that of the 10 companies responding to the question (just over half of all those in the survey) a quarter said that their works committee was motivated to develop WLB measures and a range of practical measures were provided in these companies, e.g. cash benefits for parents using crèches, paid holiday centre places or cash payments towards holiday places, payment to cover educational trips abroad.

Direct union influence in the implementation of policies was, however, reported to be even more limited than in formulation of policy in both sectors: HR officers identified line managers and HR departments as the main points of access for employees wishing to take up WLB measures, with trade unions providing a means of access in fewer than 10 per cent of reported cases (and in no cases in UK insurance).

While confirming the relatively marginal nature of the unions' role in the formulation of WLB policy and its implementation, our questionnaire nevertheless identified a small space for trade union initiative (and a relatively significant space for initiative in UK social work) in these areas, which may suggest an emerging opportunity structure for unions. It also indicated the possibility of indirect influence for French trade unions via the operation of works committees.

This being the case, we explored the unions' role in our case-study interviews with local union representatives and the relationship between the WLB agenda and other priorities; we also sought to relate these findings to national-level policy for the unions concerned. Our questionnaire findings only enabled us to track the influence of trade unions in the formulation and implementation of WLB policy and not the role trade unions may be playing in the negotiation of WLB in practice in work organizations. We sought to counter this as best as we could through our interviews with national-level union officers and with local union representatives in case-study organizations. Our study, however, is not necessarily representative of trade union activity in the two countries, nor is it intended as such; rather, it is intended to illustrate debates and initiatives in some sectors.

In our discussion below, in line with the opportunity structures identified above, we focus first on gender politics, linking the salience of WLB issues to gender-equality concerns within the union and to the gender composition of the sector, the union and its leadership structures. We then move to a discussion of the impact of working time regimes on attitudes towards worktime flexibility and modes of action, partnership being a significant corollary of WLB campaigning in the UK. In our conclusion, we discuss the implications of our findings for the broader debate about trade unions and WLB, and the possibility for future development of this emergent space for union action. The approach we adopted — based on identifying broad themes and linking them to opportunity structures — emerged 'bottom-up' from our 
interviews, and the discussion that follows is necessarily asymmetrical, because of the different configuration of opportunity structures in each country.

\section{Gender politics, equality and gender mainstreaming}

Women make up approximately 40 per cent of union members in the EU, but around 20 to 30 per cent of members of executive committees and other leadership bodies (Dean 2006). Studies suggest that 'glass ceiling' effects in trade unions remain stubborn (Ardura and Silvera 2001; Dean 2006; Guillaume and Pochic 2007; Trot and Zylberberg-Hocquard 2001) across EU member-states, apart from in Scandinavian countries where unions had already developed extensive mechanisms for female participation at all levels, in line with those societies' broader culture of gender equality in paid and unpaid work. In France, women represent 42 per cent of CFDT members, but 30 per cent of members of the national bureau, and much smaller proportions at the very top (Trot and Zylberberg-Hocquard 2001: 231); with a lower female membership ( 28 per cent), the proportion of women on the CGT's ruling bodies has increased in recent years and is in line with, if not higher than, membership, according to the CGT's own figures. Beyond the structural obstacles deriving from the gendered division of labour, gender inequalities within French union leadership structures have been attributed to old-style ways of conducting meetings including timing of meetings and styles of discussion; and 'virile' cultures of action in some unions, such as the CGT (Trot and Zylberberg-Hocquard 2001), which necessitate the introduction of deliberative structures reserved for women, and/or quotas in leadership bodies. The TUC, by contrast, with around 40 per cent female membership, has similar proportions of women in leading positions, as do its 10 largest affiliates, thanks to quotas and representative mechanisms for women adopted in the late 1990s; however, other affiliated unions do less well.

Consequently, advocates of change recommend the introduction of gender-specific mechanisms of representation and decision-making at all levels, in addition to a gender mainstreaming approach which ensures that gender is taken into account in all policies, campaigns and bargaining (Dean 2006). Gender mainstreaming is seen as offering a breakthrough for feminization strategies, insofar as it benefits from a political opportunity structure and a discursive space (Ardura and Silvera 2001). From a union perspective (especially that of the ETUC), gender mainstreaming also anchors unions' role in social dialogue and allows them to progress in a key area (female membership) where they need to prove their representativeness as an EU policy actor. However, even where gender maintreaming strategies are adopted, it has been argued that such strategies rest on an acceptance of liberal paradigms of equality, which treat the symptoms of discrimination and therefore fail to tackle the deeper causes (Kirton and Greene 2005). 
Our interviews with the women's officers for the main French trade unions found recognition of the need to feminize bargaining and awareness of gender mainstreaming. Unions were also focusing on increasing the proportion of their women members. In the CFDT's 2003 guide to bargaining on equality, Négocier l'égalité professionnelle entre les hommes et les femmes, distributed to its teams of union representatives, the union explicitly decries the imbalance of the sexes in bargaining on equality.

We are aware of and concerned by the fact that in many sectors bargaining teams are male-dominated, which hinders gender equality from being taken into account.

In the CGT too, women's officers argued that progress had been made in increasing female presence on confederal decision-making bodies, and that the next step was to recruit more women to representative and bargaining roles in the workplace.

Within the debates and initiatives on gender equality, unions reported finding that paying greater attention to the interests and priorities of women members changes the bargaining agenda. The role women have to play within the unions was also described by the CGT women's officer as varying according to their individual perception of themselves as women and to other factors such as the sector of employment:

The number of women directly affects the bargaining agenda ... Depending on the number of women and their subjective view of their condition, things are different.

As noted above, the Génisson law on gender equality provided an opportunity to raise the issue of WLB in bargaining. As a result, the CFDT developed a specific training and awareness campaign for bargaining representatives, entitled 'Equality has to be negotiated' ('L'égalité, ça se négocie'). Our interviews confirmed a growing interest in WLB within the major union confederations and consciousness raising through working groups, workshops and surveys. The Génisson law thus appears to have had a longer-term, awareness-raising impact on unions.

But in most of the unions the issue is not addressed head-on, as the CGT's women's officer acknowledged.

It hasn't really become part of our [bargaining] culture that we speak about [work-life balance] in the same way we speak about other issues, and that's one of the problems we find.

As the CFDT's women's officer explained, WLB is still seen as a no-go area for bargaining, because it introduces non-work elements, which do not traditionally belong to the sphere of collective bargaining, and which are seen as women's responsibility. This explains why in France WLB has to be addressed indirectly, through the prism of gender equality at work, and tends to be framed in gendered terms: 
The issues we've concentrated on ... have been the most visible inequalities in the workplace such as the wage gap, inequalities in access to training and promotion ... because it's more concrete . . . and also another reason that we work less on [WLB] in the trade unions is that we live in a society where there's a culture of the family and the home being women's responsibility, it's not questioned in our society today, even by younger men . . . Even the discourse . . . it hasn't shifted, it's deep-rooted . . . In the union, it's the same, even though the negotiating teams may be ready to fight over wage inequality or inequalities in the labour market, where it's concrete ... they're not ready to take on issues relating to family responsibilities, first of all because they're not ready to take them on themselves as men.

In the UK, the TUC too has developed mechanisms to promote and audit gender equality in its own structures, within the broader context of campaigning against multiple forms of discrimination and disadvantage. Under the heading of equality, the TUC notes the specificity of bargaining on 'women's' issues: for example, the TUC's 2003 equality audit identified two major sets of issues in bargaining on behalf of female members: equal pay (the priority for 56 per cent of unions) and WLB, including 'flexible working' (TUC 2003).

Unions have also addressed the gender segregation associated with the UK's male breadwinner/female part-time carer model. They note that in some cases parents are unable to access flexible or part-time working arrangements when they need them for childcare reasons (see TUC 2005a). The TUC therefore calls for a strengthening of the current law governing the right to request flexible working for parents of children aged six and under, and its extension to all employees: 'It is only by making flexible working, and thus part time working, more normal across occupations, sectors and industries [that we will] begin to lift the penalties against those who currently work part-time' (TUC 2005a: 9). In 2008, the TUC's message appeared to have been heeded, as the government announced its intention to extend flexible working rights to all parents; however, by October 2008, as the economy faced the prospect of recession, this announcement was countered by the government's willingness to consider restrictions on flexible working rights on business grounds.

This characteristic of the UK labour market helps to explain why, unlike the French unions, however, the TUC has run a highly visible campaign specifically on WLB, which it links with working time and flexibility: according to general secretary Brendan Barber, WLB was the most important campaign issue for 2005, alongside pensions. The TUC's on-line regular guide to WLB ('Changing Times') provides a useful and comprehensive survey of developments in the area, together with international comparisons. The TUC has published a guide to negotiating WLB (TUC 2001) and a bargaining toolkit. ${ }^{4}$ In this it has responded to government initiatives in a way that highlights the gap between government intentions and the measures offered, for example, on the practical difficulties faced by parents wishing to take up parental leaves or the right to work flexibly to meet their needs. The TUC has also sought to demonstrate the business case for WLB. 
Although the TUC is aware that there are particular gender issues raised by WLB, it argues, in line with thinking promoted by the Equal Opportunities Commission, that WLB must not be viewed as a women's issue, but must transcend 'gender stereotypes'. In other words, the TUC's strategy has been to 'play government and business at their own game'. In cross-national terms, the TUC's position may be interpreted in the light of its role as an umbrella organization, with no direct mandate for bargaining, but the possibility of influencing public debates and lobbying for employment legislation, as well as in the light of its modernization strategy, which combines organizational and policy renewal (Colgan and Ledwith 2002).

The TUC's position, however, does inform the bargaining strategy and practice of its affiliated unions. One of the largest of these, the public sector union Unison, has the most developed policy on WLB, with a full-time officer responsible for WLB and a highly informative website, which is the TUC's main electronic resource link. At the time of interview (May 2003), Unison's policy officer reported that as part of its ongoing campaign, WLB policy was being regionalized, with regional co-ordinators to be identified and trained at national HQ. Unison's concern, since its creation, with ensuring full representation of women and minority groups (McBride 2000, 2001) means it has been cited as an example of best practice not just within the UK, but within Europe: 'the first trade union in the UK to take on board an extensive range of strategies relating to the representation and participation of individual women and women as a social group' (Dean 2006: 35). As we discuss below, Unison's two flagship projects on WLB in Bristol city council and Merton borough council remain the most widely cited cases of bargaining on WLB, and serve as models in the TUC's guides to bargaining on the issue.

Thus, in both countries, it is evident that the presence of women in representative and leadership positions within unions influences the bargaining agenda and is likely to determine the salience of WLB issues. In the UK, despite the unions' consciously gender-neutral campaigning, the presence of women in key bargaining and campaigning posts was a key factor in getting the issues on to the agenda. For example, in the Bristol city council case, which we discuss below (see Box 1), the three main agents of change pushing for a WLB policy (trade union branch secretary, TUC officer, local government officer) were all women (interview with trade union branch secretary). Our interviews with local union representatives also reinforced the perception that WLB is often (not in all cases) seen as primarily a women's issue.

At policy level (national campaigns and bargaining strategies) the salience and, particularly, the content of WLB issues are also strongly influenced by the nature of legislative initiatives and the opportunity structures they present, as well as constraints posed by the specificities of the labour market and cultural attitudes about gender roles. In the following section we discuss this in relation to flexibility in the UK case and reduced work-time in the French case. 


\section{BOX 1 \\ The 'Time of Our Lives' Project in Bristol City Council, UK}

The (ongoing) 'Time of Our Lives' project was 'an ambitious WLB project which obtained win-win results for staff and managers in a range of services' (TUC 2001: 7), resting on a 'positive model of flexibility' (Cressey 2002). According to the TUC's WLB officer (interview, January 2005), Bristol 'sowed the seeds' for a distinctive approach combining improved service delivery and WLB for employees.

The project arose when the TUC was looking for a project to pilot the 'new flexibility'. Bristol city council was receptive because it was under pressure to improve service delivery. Two pilot projects were selected in environmental services and in library services, where the council had found strong customer demand for longer opening hours. In environmental services, it was felt that a variety of new working practices (compressed hours, some home working) could help to introduce new shift patterns while allowing some men greater flexibility in avoiding rush-hour traffic. Here, the predominantly male workforce was initially resistant to changes in work patterns. However, the need to find solutions that suited a group with diverse personal requirements meant that the process of negotiating change itself was important and encouraged innovation. The consultation phase of the project confirmed that the project would only work if it avoided targeting mothers, or parents, but promoted flexibility for all, regardless of the motive.

Partnership was found to bring inevitable delays and frustrations, in comparison with a top-down, management-driven approach, but it allowed mistrust to be broken down and therefore ensured a greater chance of long-term success (TUC 1999). A further supportive element was provided by the European Commission, which funded conferences on 'the times of the city' attended by the Bristol WLB champions, and subsequent exchange visits. The 'times of the city' experiments in Italy and the Netherlands served as an example of how improved service delivery (extended front-office hours) could be combined with greater flexibility for employees, but it also depended on good childcare facilities for working parents (Pillinger 1998; see also Belloni et al. 1998). Initial contacts with Dutch and Italian trade unionists were made during an ILO conference in 1992 (interviews, TUC and local Unison representative).

\section{Trade unions, flexibility and WLB}

The discourse of WLB implies a 'win-win' strategy of 'positive flexibility', which may give unions the opportunity to (re)gain influence, especially where 
unions find themselves under pressure from an alternative scenario of outsourcing and redundancies. WLB, which is equated with flexibility, nevertheless poses high risks for unions that accept a seat at the negotiating table, as it may simply be a way of legitimating employer-friendly, flexible work practices (Fleetwood 2007). In France, many unions continue to see flexibility as employee-unfriendly, and have only been willing to accept it when it is severely constrained by legal limits (such as overtime ceilings or durationspecific clauses) or balanced by real working-time reduction.

The Aubry legislation was framed in terms of promoting a 'mutual gains' strategy, whereby unions would trade flexibility for increased non-work time. However, bargaining on the 35-hour week tended not to frame it in terms of WLB, and where it does, it refers narrowly to mothers' caring responsibilities. The reasons for the separation of WLB and working-time reduction (RTT) were seen by our respondents as being linked to the fact that the teams mainly engaged in bargaining on RTT were men, for whom WLB issues were not a priority, as they did not themselves carry equal responsibility for unpaid work in their homes. For example, in the CGT's bargaining guidelines on negotiating reduced working time, the only mention of WLB is in relation to the organization of training measures to take into account the travel difficulties of parents and childcare constraints, and guarantees that maternity leave will not prevent a woman from being promoted (CGT 2000: 75). On the other hand, the guide concentrates on work organization issues that directly relate to WLB but does not refer to it as such: in particular, annualized hours, which the CGT seeks to prevent wherever possible, and part-time working, which the CGT wishes to limit to 'chosen' part-time work. The French unions also take a harder line than their UK counterparts on non-standard working hours, reflecting the differing working time regime outlined above.

In French unions generally, part-time work is viewed with suspicion because of fears of reinforced gender segregation.

It's clear that there's a real block on their career if men take up [part-time work] and parental leave, so you see there are two things that work together - men don't necessarily need to take up these measures, and employers take it badly if men ask for them. (CFDT Women's officer)

Overall, French trade unions have not bought into the business case for flexibility, which they see as employee-unfriendly. In practice, trade union pluralism in France has allowed some unions to maintain maximalist positions, while others have negotiated agreements that brought in significant employer-friendly flexibility. In particular, contrary to the spirit of the law, many RTT agreements were used to usher in annualized hours. In our research, this was particularly in evidence in insurance, as can be seen in one of our case studies (Box 2), where new flexible roster systems were introduced. Also, family-friendly measures were framed in traditional paternalist terms, allowing women to work around school hours, rather than in broader 


\section{BOX 2 \\ French Insurance Company B}

The group has a strong history of family-friendly measures, notably of part-time working and a short working week, developed primarily out of a paternalist concern in the 1980s and early 1990s (early agreements relating to flexitime and part-time working for parents of school-age children). All the recognized unions are present as well as the UDPA (an independent union). In the last group elections 38 per cent of the votes went to the CFDT, 15.2 per cent to the CGT, 15.8 per cent to the CFTC, 13.5 per cent to the CGC, 9.9 per cent to FO and 5.9 per cent to the UDPA.

The main change to working hours resulted from the group's agreement of 1 February 2000 on the reorganization and reduction of working time, following the legislation to reduce the working week to 35 hours. Only two unions (CFDT and CGC) signed the agreement, which implemented a 5-6 per cent reduction in working time, with no reduction in salary at a time when the company needed to undergo major work organization in order to become more competitive. The CGT and FO had refused to sign the agreement because no jobs were being created with the agreement (in fact jobs were cut). The agreement brought in with it a new system of work organization (shift patterns and rotas), which was negotiated separately across the various companies in the group, with a computerized time management system and an agreement to integrate staff's working hours preferences into the planning of working hours. Article 4.3 of the agreement states that particular consideration of managers' difficulties in managing work and family life will be given by the group; this had not taken place at the time of the interviews.

Two further rounds of group-level bargaining took place in April 2001, leading to an agreement on how managers would take their days off under the shorter working hours regime and another on a form of term-time working (allowing staff 10 weeks off a year for child-care reasons); this replaced the previous part-time working for school-age children agreement. Paternity leave was introduced into the company according to the legal statues, with no extra provision; all the unions called for the two weeks' leave on enhanced pay, but the company maintained its minimalist position. Instead, at the time of the interviews, the unions were still engaged in negotiations connected to the application of the work reorganization to call centres, as formerly back office work and brokers' work - such as dealing with claims - was being transferred into call centres.

At the time of the interviews, the obligations of the Génisson law were being considered. The company was obliged to produce an equality report a summary of the situation of men and women according to a number of criteria - but the subject was not being championed within the company (despite a senior manager being put in charge of the question on how to achieve more women in top jobs) and the link between working hours and opportunities for women to progress their careers had not been made. The CGT had requested the setting-up of an equality working group in order to examine a wider range of criteria (an optional feature of the law) but this had not transpired as of June 2003. 


\section{BOX 3 \\ UK Insurance Company A (a Subsidiary of French Insurance Company B)}

Approximately 60 per cent of staff are members of Amicus. Insurance company A (INCO A) has a partnership agreement with the union. There is an effective set of committees for joint consultation including a joint consultative committee with monthly meetings. There is also a European Works Committee (with a social sub-committee) dealing with cross-European issues including call centres. However WLB issues are not standing items on either of these committees.

Nevertheless as part of the partnership agreement Amicus has been engaged in consultations with the group over a range of issues and a consultation template has been developed for every new project affecting staff. The mechanisms are therefore present to allow discussion of WLB issues. In addition, there has been a gradual spreading of unionization across the whole group, starting with shared services in HR, IT and finance, which has been related to the process of merger and acquisition within the group. The best family-friendly policy in one of the group's companies has been used as a template for the harmonization of terms and conditions, which has been driven forward by the union. The union feels that the group offers one of the better ranges of provisions for family-friendly working in the industry and that its co-operation with the group in this area has been positive.

The union's approach is to tackle a policy area that had not been examined every year. From 2000 onwards it targeted family-friendly issues and equal pay.

The union has, in particular, helped to introduce adoption leave. Amicus has also contributed to promoting the group's family-friendly working measures.

Another forum, the group's E\&D Forum, should have been a main plank of family-friendly working (with bimonthly meetings), but the first attempts to establish it were ineffective and the union hopes it will be re-established with a new champion. The E\&D forum was delayed in part by the development of a group harmonization initiative in the UK.

WLB terms, and were again employer-led, with unions unable to exert leverage in bargaining, for example, over paternity leave.

Our findings corroborate those of a representative study of RTT agreements (Defalvard et al. 2005), which identified a clear gender effect of the 'mandating' mechanism introduced by the first Aubry law, allowing trade unions to mandate bargaining representatives in workplaces with no trade union delegate. Fifty per cent of Aubry I company-level agreements were signed by mandated representatives, with 30 per cent signed by trade union delegates 
and a further 20 per cent incorporating sectoral agreements. Although only 20 per cent of official bargaining delegates were women, 40 per cent of mandated negotiators on working time were women. Female negotiators were found to pursue an agenda of employee-friendly flexibility. However, these negotiators were predominantly situated in workplaces with weak or non-existent representative structures, and as a result they had less leverage than elsewhere to resist employer-driven flexibility. Moreover, WLB issues in bargaining were hampered by entrenched attitudes within the union, reinforcing gender segmentation in working time strategies. Nevertheless, the study found evidence that the increased presence of women in bargaining positions, together with a new opportunity structure for bargaining, resulted in a new awareness and discussion of WLB within unions at all levels.

In the case of British unions, the opportunity structure for the development of WLB issues has meant a shift towards a 'mutual gains' strategy which implies a co-operative approach to employment relations. In some cases, as we shall see in the next section, this has entailed more or less formal partnership working. In terms of the content of bargaining, it has also meant that WLB is conceptualized as flexibility that is both employer-friendly and employee-friendly.

The issue of flexibility was dominated in the 1980s and 1990s by British employers' need to respond to competitive markets, resulting in little or no worker control over working arrangements in increasingly insecure labour market conditions. For women in particular, flexibility meant a marked deterioration in working conditions and increased work-life stress in the context of an unequal division of unpaid work. This meant that 'the old debate framed the issue in negative terms and made it gender-related, highlighting above all the domestic and childcare constraints pushing women workers into such arrangements' (Cressey 2002: 354). Trade unions consequently viewed any proposal for flexibility with suspicion.

The UK's widespread use of employer-friendly flexibility made it something of an exception in EU Europe, where workplace regulation was often greater and work intensification was taking place more slowly (Burchell 2006). On work intensification and workplace stress, the TUC has been something of an agenda setter. As its then general secretary John Monks argued (TUC 2001: 1),

British men work the longest hours in the $\mathrm{EU}$, stress is the greatest cause of absence from work, many organizations have not introduced family-friendly working, despite the encouragement of government and positive reports from those farsighted organizations which have.

In campaigning on the UK's long-hours culture, the TUC was also concerned to regain the public influence it had lost in the last decades; as it noted in its response to the DTI consultation on the 2005 Work and Families Bill.

The DTI's approach to flexible working in its consultation focuses on the individual employee and the employer, with no mention of trade unions. The TUC 
argues that in addition to an individual right to work flexibly there needs to be a collective response to the organisation of working time. (TUC 2005b: 25)

The trade unions' ability to campaign successfully on WLB issues depended to a large extent on a change in government policy since 1997, with the subsequent enactment of the 1999 Employment Relations Act (see also Heery 2006a). According to Cressey (2002), the additional dimension of legislative promotion of employee-friendly flexibility provided unions with an opportunity to reframe the terms of the debate, although in practice the government generally prefers a 'soft', non-statutory route to WLB and family-friendly policies.

Moreover, in the public sector the drive to modernize customer service delivery has created a similar space for trade unions to engage in the search for possible 'mutual gains' situations (Cressey 2002; Morris and Pillinger 2007; see also case study in Box 1). More generally, the TUC's approach has necessarily been ad hoc and project-based (interview with local Unison representative), and thus heavily dependent on locally favourable conditions, in particular, championing by individual managers. Public-sector employers are felt to be particularly receptive to the equality logic of WLB policies, whereas the private sector has to be convinced on the business case (interview with national policy officer, Unison; see also Heery 2006a). The dominance of the public sector in promoting bargained WLB confirms the weakness of the trade union agenda in the private sector. In the public sector, WLB may be a way of restructuring employment conditions in a sector where employees have been relatively protected in the past but are facing new threats to their job security owing to a new neoliberal logic.

Thus, we see that attitudes to flexibility condition the unions' approach to WLB. In both countries, equality and working-time legislation have provided an opportunity structure conducive to a programmatic change and more active role for trade unions; however, the mode of implementation is also significant. In France, legislation has expressly created a space for bargaining, but in many cases unions have been too weak and vulnerable to move beyond defensive positions. In the UK, legislation is dependent on employers' willingness to implement it, and the unions' role is therefore strongly circumscribed. In both countries, the public sector is an important site of the development of WLB measures. In France the unions' role is buttressed by legal safeguards concerning the employment status of public servants (and hence any flexibility tends to be employee-friendly and negotiated within the context of reduced working time, with annualized hours and home working expressly excluded); on the other hand, flexibility is achieved 'on the margins' through the use of part-time work in some cases, and by the widespread use of casual, non-contractual staff. In the UK, the trade union WLB agenda has been strongly influenced by initiatives in the public sector, supported by legislation and by EU initiatives and networks; however, there is also at least an element of constraint in the broader context of outsourcing, restructuring and intensified workloads. 


\section{WLB, partnership and modes of action}

As we have seen, in our questionnaires to HR officers about the availability of WLB policies and reasons for their introduction, trade unions appeared as relatively marginal actors. In both countries, policies were generally driven by legislative change, by top-level corporate strategies aimed at rebranding the organization as an 'employer of choice', or by HR departments seeking to resolve specific problems identified with recruitment or loss of human capital (absenteeism, high turnover, low rates of women returners), although unions were often involved at the implementation stage. In the UK, unions therefore tended to frame the issues in defensive terms, identifying problems around particular forms of flexibility, such as working from home or hot-desking. It also helps to explain why, in some cases, employees we interviewed did not tend to turn to unions for information or support when seeking to take up 'their' WLB measures.

In France, the unions' role was largely determined by the process of collective bargaining, itself driven by legislative impetus, as we have seen. In the UK, trade unions were more marginal actors, although unions have pioneered WLB in a number of flagship cases, where the development of partnership with employers has also been a key feature. Indeed, partnership can be seen in this respect as a prerequisite for the successful implementation of trade union initiatives in WLB.

According to the TUC, achieving WLB 'requires management and unions to work together in partnership'. Partnership is based on a series of principles: shared commitment to the organization's success; commitment by the employer to job security; focus on the quality of work; recognition of employers' and trade unions' legitimate roles; willingness to share information; adding value in terms of improvements for the organization and the employee (TUC 2001). Partnership is a key objective of the TUC, which set up a Partnership Institute to spread the practice, as yet confined to a small number of organizations.

As previously noted, many of the TUC's flagship WLB projects have involved the public-sector union, Unison. Unison (2002) participated in a number of pilot projects funded by the Challenge Fund (according to its 2002 annual conference, over half of the participating organizations had Unison representation). The Challenge Fund, launched in 2000 to support the design and implementation of WLB projects over a 12-month period, financed 266 projects in the first four rounds (2000-2003) and a further 131 smaller projects in the fourth round (Nelson et al. 2004). Applications to the Challenge Fund came disproportionately from the public and voluntary sectors. An evaluation of the first three rounds commissioned by the DTI concluded that significant changes in working practice had taken place, and that awareness of WLB issues had been raised (Nelson et al. 2004). It also confirmed the unions' belief that a participative approach works best. From Unison's point of view, the Challenge Fund projects had raised other problems, particularly regarding the input of external consultants on whom the bulk of the funding had been spent. 
Unison carried out its own evaluation before the DTI's official review was published (to the latter's displeasure), which revealed dissatisfaction with the role of consultants (chosen by the government) who tended to leave the projects early on (Unison interview). One of the first-round case studies chosen for the DTI evaluation was the Merton borough council, Unison's other flagship project alongside Bristol city council (see Box 1).

As noted in Richardson et al.'s (2005; see also Stuart and Martinez Lucio 2005) review of academic literature on partnerships (mainly in the public sector), partnership is closely bound up with the achievement of internal and external flexibility, and their own study of a local authority confirmed this link between partnership and flexibility. One consequence of partnership, they suggest, is that its purpose, benefits and disadvantages tend to be communicated downwards, with little employee participation and involvement. Partnership is therefore not without risks, not least the risk of increasing distance between local union representatives and members. However, the process at Bristol and Merton was initiated by top-level partnership, but policy implementation rested on direct discussions and negotiations throughout by the work groups concerned; in this sense, the unions acted as initiator, but also as broker.

More generally, then, WLB policies require a new form of intervention by trade unionists (whether approaching the issue from local, regional or national level). Gerson noted that, in the USA, trade unions were slow to take up WLB issues because their membership was often divided about the benefits, and prioritized material benefits over working time. In the UK, the TUC's promotion of WLB brought with it a conscious change of role for trade unions. First, the TUC's officer (interview) emphasized that projects such as Bristol or Merton need a lot of steering 'they don't just happen'. Initially, in Bristol, library staff were distrustful of changes to work schedules because of recent reorganizations. Similarly, in the Inland Revenue project, many staff resisted change at first because they feared a shift of control over their working arrangements to customers. Focus groups proved to be the main method by which employees were encouraged to rethink their working hours and move beyond a defensive reflex about existing arrangements.

Our interviews in the insurance industry showed that partnership may also bring about a slower long-term change as unions are brought into consultative relationships, which may develop to involve new substantive issues such as working time and other related issues (see Box 3). However, at the time of the interviews, such relationships had not yet developed and the union's role remained consultative.

\section{Conclusion}

Cross-national comparisons of the role of trade unions in WLB are rare, and not much is known about the factors determining this role.

Our study confirmed that unions are relatively marginal actors in the process of introducing and implementing WLB policies, and that 
employer-led initiatives often place them in a defensive position. In this respect our research corroborates similar findings on British unions' role in bargaining on diversity, where the irony of union engagement is that it is taking place 'at a time when their influence and ability to act at workplace level is relatively weak' (Kirton and Greene 2006: 432; see also Colling and Dickens 2001). However, we also found instances in the UK where trade unions had been able to drive the process from an early stage as part of a mutual gains strategy, and cases where the process of bargaining reduced working time in France had led the unions into negotiations over WLB issues, albeit often from a defensive position. We also found instances where employer-led initiatives provided a space for unions to be involved and to try to steer the agenda towards the adoption of employee-friendly measures or at least to try to avoid or to monitor the impact of other measures they considered less employee-friendly (such as hot-desking, annualized working hours and, in some cases, homeworking).

Our findings show in particular that unions are dependent on structures of opportunity, especially the space created by national working time (and social) policy, but also European policy and projects, and organizational initiatives. The flagship projects cited have taken advantage of all three structures of opportunity. In particular, the new policy initiatives around equal opportunities and diversity have opened up a space for policy and process innovation within trade unions in both countries. This finding is in line with existing analysis for the UK (Kersley et al. 2006; Wood et al. 2003), which found a strong link between the existence of equal opportunities policies and WLB policies in the workplace; it is confirmed in our survey for both countries. Our interviews with trade union representatives also bore this out, particularly for France.

In terms of taking the initiative on WLB, the literature and our own interviews suggest that the presence of women in union structure is crucial. In terms of outcomes, union involvement is seen as dependent on bargaining structures and leverage within the workplace, while organizational initiatives are seen to be important drivers of change. In this article we have highlighted in particular the differing approaches taken by employers (and trade unions) to WLB and work-time organization in social work and insurance, and have shown key differences in approaches in the public versus the private sector.

The link between certain types of managerial practice and legislative initiatives has created a space for union initiatives in a limited number of cases where there is a trade-off between employer-friendly and employee-friendly flexibility. This is particularly true for the UK, in line with earlier studies about the link between modernization of union strategies and "positive flexibility' (Cressey 2002; Heery 2006a,b). From a union point of view, there are significant risks involved in terms of union member relations in a context of increased job insecurity, which often accompanies employer-led flexibility. However, our findings suggest that this new agenda also offers a space for innovation. Modernization, linked to internal organizational change, may 
therefore be seen as an opportunity as well as a risk, that of accepting the business agenda and thereby the imposition of employer-friendly flexibility.

Final version accepted on 30 October 2008.

\section{Notes}

1. Work-life balance (WLB) can be defined as 'the relationship between the institutional and cultural times and spaces of work and non-work in societies where income is predominantly generated and distributed through labour markets' (Felstead et al. 2002: 56). WLB practices in the workplace are therefore those that, intentionally or otherwise, increase the flexibility and autonomy of the worker in negotiating attention (time) and presence in employment; while WLB policies exist where those practices are intentionally designed and implemented. WLB is a term that is increasingly contested (for a full discussion see Gregory and Milner 2009), with authors recently advancing other alternatives such as work-life integration and work-life articulation. We have chosen to retain the long-standing and better known term in this article.

2. In insurance, CNPF and CFTC representatives were also interviewed in the casestudy organizations and at federation level; FO was also interviewed at the confederation level.

3. Thirty companies replied in British insurance (a response rate of 20 per cent), compared with 36.5 per cent (21 companies) in French insurance. The respondents were representative of the industry in terms of company size and union representation. In social work the response rate was 38 per cent (22 out of 60 local authorities) in Britain and 20 per cent in France (12 out of 60 departments contacted; here the very low number of responses still allowed for analysis as there is a high degree of standardization of employment practices due to the specific status of public-sector employees).

4. The guide cites several case studies of successful WLB agreements involving TUCaffiliated unions including (in the public sector) Bristol city council (see below), Redditch city council, the Inland Revenue and North Manchester General Hospital, and (in the private sector) Sainsbury's, Lloyds TSB, British Telecom, the Cooperative Bank and the water and electricity utility Hyder plc.

\section{References}

Ackers, P. (2002). 'Reframing employment relations: the case for neo-pluralism'. Industrial Relations Journal, 33 (1): 2-19.

Ardura, A. and Silvera, R. (2001). 'L'égalité hommes-femmes: quelles stratégies hommes-femmes?'. Revue de l'IRES, 3 (37): 1-25.

Bagilhole, B. and Byrne, P. (2000). 'From hard law to soft law and from equality to reconciliation in the UK'. In L. Hantrais (ed.), Gendered Policies in Europe. Reconciling Employment and Family Life. Basingstoke and New York: Palgrave Macmillan, pp. 124 42.

Bardoel, A. E., Moss, S. A., Smyrnios, K. and Tharenou, P. (1999). 'Employee characteristics associated with the provision of work-family policies and programs'. International Journal of Manpower, 20 (8): 563-76. 
Belloni, M.-C., Boulin, J.-Y. and Junter-Loiseau, A. (1998). 'Du temps de travail aux temps de la ville'. In M. Maruani (ed.), Les nouvelles frontières de l'inégalité. Hommes et femmes sur le marché du travail. Paris: La Découverte, pp. 169-82.

Bewley, H. and Fernie, S. (2003). 'What do unions do for women?'. In H. Gospel and S. Wood (eds.), Representing Workers: Union Membership in Britain, Vol. I. London: Routledge, pp. 92-118.

Budd, J. W. and Mumford, K. (2004). 'Trade unions and family-friendly policies in Britain'. Industrial and Labor Relations Review, 57 (2): 204-22.

Burchell, B. J. (2006). 'Work intensification in the UK'. In D. Perrons, C. Fagan, L. McDowell, K. Ray and K. Ward (eds.), Gender Divisions and Working Time in the New Economy. Cheltenham: Edward Elgar, pp. 21-34.

Coleman, M. and Hasting, S. (1993). Les femmes et les syndicats en Europe. Geneva: ILO.

Colgan, F. and Ledwith, S. (eds.) (2002). Gender, Diversity and Trade Unions. International Perspectives. London and New York: Routledge.

Colling, T. and Dickens, L. (2001). 'Gender equality and trade unions: a new basis for mobilisation?'. In M. Noon and E. Ogbonna (eds.), Equality, Diversity and Disadvantage in Employment. Basingstoke: Palgrave, pp. 136-55.

Confédération Française Démocratique du Travail (CFDT) (2003). Négocier l'égalité professionnelle. Paris: CFDT.

Confédération Générale du Travail (CGT) (2000). Gagnons du Temps: Repères CGT pour Négocier la RTT. Limoges: Rivet Presse Edition.

Cressey, P. (2002). 'Women and atypical working in the United Kingdom: the prospects for positive flexibility'. In H. Sarfati and G. Bonoli (eds.), Labour Market and Social Protection Reforms in International Perspective. Aldershot/Burlington, VT: Ashgate, pp. 353-71.

Dean, H. (2006). Women in Trade Unions. Methods and Good Practices for Gender Mainstreaming. Brussels: European Trade Union Institute.

Defalvard, H., Lurol, M. and Polzhuber, E. (2005). 'Les inégalités de genre dans le passage aux 35 heures, sources et resistances'. Travail et Emploi, 102: 45-56.

Demetriades, S., Meixner, M. and Barry, A. (2006). Reconciliation of Work and Family Life and Collective Bargaining in the European Union. An Analysis of EIRO Articles. Dublin: European Foundation for the Improvement of Living and Working Conditions.

Dickens, L., Townley, B. and Winchester, D. (1988). Tackling Sex Discrimination through Collective Bargaining. London: HMSO.

European Union (EU) (2007). Report from the Commission to the Council, the European Parliament, the European Social and Economic Committee, and the Committee of the Regions on equality between women and men. Brussels. COM (2007) 49 final.

Fagnani, J. and Letablier, M.-T. (2007). 'The French 35-hour working law and the work-life balance of parents: friend or foe?'. In D. Perrons, C. Fagan, L. McDowell, K. Ray and K. Ward (eds.), Gender Divisions and Working Time in the New Economy. Cheltenham: Edward Elgar, pp. 79-90.

Felstead, A., Jewson, N., Phizacklea, A. and Walters, S. (2002). 'Opportunities to work at home in the context of work-life balance'. Human Resource Management Journal, 12 (1): 54-76.

Fleetwood, S. (2007). 'Why work-life balance now?'. International Journal of Human Resource Management, 18 (3): 387-400. 
Franco, A. and Winqvist, K. (2002). 'Women and men reconciling family life'. Statistics in Focus: Population and Social Conditions. Theme 3, 9/2002.

Gambles, R., Lewis, S. and Rapoport, R. (2006). The Myth of Work-Life Balance: The Challenge of Our Time for Men, Women and Societies. Chichester: Wiley.

Gerstel, N. and Clawson, D. (2001). 'Unions' responses to family concerns'. Social Problems, 48 (2): 277-97.

— and - (2002). 'Unions' responses to family concerns'. In N. Gerstel, D. Clawson and R. Zussman (eds.), Families at Work. Expanding the Bounds. Nashville: Vanderbilt University Press, pp. 317-42.

Gregory, A. and Milner, S. (2006). 'Les entreprises et la conciliation de la vie professionnelle et familiale'. Recherches et Prévisions, 85: 5-27.

— and - (2008). 'Fatherhood regimes and father involvement in Britain and France'. Community Work and Family, 11 (1): 61-84.

— and (2009). 'Introduction. Work-life balance: a matter of choice?'. Gender, Work and Organization, 15 (1): 1-13.

Guillaume, C. and Pochic, S. (2007). 'Le syndicalisme à l'épreuve de la féminisation: la permanence paradoxale du plafond de verre à la CFDT'. Politix, 78.

Hantrais, L. (ed.) (2000). Gendered Policies in Europe. Reconciling Employment and Family Life. Basingstoke and New York: Palgrave Macmillan.

— and Ackers, P. (2005). 'Women's choices in Europe: striking the work-life balance'. European Journal of Industrial Relations, 11 (2): 197-212.

Hardy, S. and Adnett, N. (2002). 'The parental leave directive: a family-friendly social Europe?'. European Journal of Industrial Relations, 8 (2): 157-72.

Heery, E. (2006a). 'Bargaining for balance: Union policy on work-life issues in the United Kingdom'. In P. Blyton, B. Blunsdon, K. Reed and A. Dastmalchian (eds.), Work-Life Integration. International Perspectives on the Balancing of Multiple Roles. Basingstoke: Palgrave Macmillan, pp. 42-62.

- (2006b). 'Equality bargaining: where, who and why?'. Gender, Work and Organization, 13 (6): 522-42.

Hyman, J. and Summers, J. (2007). 'Work and life: can employee representation influence balance?'. Employment Relations, 29 (4): 367-84.

Jefferys, S. (2000). 'A "Copernican revolution" in French Industrial Relations: are the times a'changing?'. British Journal of Industrial Relations, 38 (2): 241-60.

Jobert, A. (1994). 'L'égalité professionnelle dans la négociation collective'. Travail et Emploi, 63: 177-87.

Kersley, B., Alpin, C., Bryson, A. and Forth, J. (2006). Inside the Workplace. Findings from the 2004 Workplace Employment Relations Survey. London and New York: Routledge.

Kirton, G. and Greene, A. (2005). 'Gender, equality and industrial relations in the "New Europe": an introduction'. European Journal of Industrial Relations, 11 (2): $141-9$.

— and (2006). 'The discourse of diversity in unionised contexts: views from trade union equality officers'. Personnel Review, 35 (4): 431-48.

Lanquetin, M.-T., Laufer, J. and Letablier, M.-T. (2000). 'From equality to reconciliation in France?'. In L. Hantrais (ed.), Gendered Policies in Europe. Reconciling Employment and Family Life. Basingstoke and New York: Palgrave Macmillan, pp. 68-88.

Laufer, J. (1998). 'Equal opportunity between men and women: the case of France'. Feminist Economics, 4 (1): 53-69. 
Le Feuvre, N. and Lemarchant, C. (2007). 'Employment, the family and work-life balance in France'. In R. Crompton, S. Lewis and C. Lyonette (eds.), Women, Men, Work and Family in Europe. London: Palgrave, pp. 210-29.

Lewis, S. and Cooper, C. (2005). Work-Life Integration. Case Studies of Organisational Change. Chichester: John Wiley and Sons.

McBride, A. (2000). 'Promoting representation of women within UNISON'. In M. Terry (ed.), Redefining Public Sector Unionism. UNISON and the Future of Trade Unions. London and New York: Routledge, pp. 100-18.

- (2001). Gender Democracy in Trade Unions. Aldershot, Burlington, VT: Ashgate.

Morris, J. and Pillinger, J. (2007). 'Developing positive flexibility for employees: the British trade union approach'. In D. Perrons, C. Fagan, L. McDowell, K. Ray and K. Ward (eds.), Gender Divisions and Working Time in the New Economy. Cheltenham: Edward Elgar, pp. 207-24.

Nelson, A., Nemec, K., Solvik, K. and Ramsden, C. (2004). The Evaluation of the Work-Life Balance Challenge Fund. Employment Relations Research Series No. 32. London: Department of Trade and Industry.

Pillinger, J. (1998). Working Time in Europe. A European Working Time Policy in the Public Services. Brussels: European Federation of Public Service Unions.

Richardson, M., Tailby, S., Danford, A., Stewart, P. and Upchurch, M. (2005). 'Best value and workplace partnership in local government'. Personnel Review, 34 (6): 713-28.

Rubery, J., Smith, M. and Fagan, C. (1998). 'Gender, societal effects and workingtime regimes'. Feminist Economics, 4 (1): 71-101.

Stuart, M. and Martinez Lucio, M. (2005). 'Partnership and modernisation in employment relations: an introduction'. In M. Stuart and M. Martinez Lucio (eds.), Partnership and Modernisation in Employment Relations. London: Routledge, pp. 1-22.

Trades Union Congress (TUC) (1999). The Time of Our Lives in Bristol. Developing Flexibility for Employees and Services. London: TUC.

(2001). Changing Times. A TUC Guide to Work-Life Balance. London: TUC.

(2003). Equality Opportunities Audit. London: TUC.

(2005a). TUC Submission: Women and Work Commission. London: TUC.

(2005b). Work and Families, Choice and Flexibility: TUC Response. London: TUC.

Trebilcock, A. (1991). 'Pour renforcer la présence des femmes aux échelons supérieurs des syndicats: les stratégies du succès'. Revue Internationale du Travail, 130 (4): 451-73.

Trot, J. and Zylberberg-Hocquard, M.-H. (2001). 'Les femmes et le syndicalisme'. In R. Silvera and V. Estournes (eds.), Les Femmes, le Travail et la Société. Paris: VO Editions, pp. 217-46.

Unison (2002). Local Government Service Group Annual Report. London: Unison.

Walby, S. and Olsen, W. (2002). The Impact of Women's Position in the Labour Market on Pay and Implications for UK Productivity. London: Women and Equality Unit.

Women and Work Commission (2006). Shaping a Fairer Future, Executive Summary and Recommendations. February. London: HMSO.

Wood, S., de Menezes, L. M. and Lasoasa, A. (2003). 'Family-friendly management in Great Britain: testing various perspectives'. Industrial Relations, 42 (2): 221-50. 